\title{
Reflective Experiences of Students to the Integration of Role Playing Model with Multimedia in Citizenship Education
}

\author{
Apriyanda Kusuma Wijaya \\ Citizenship Education Master Program \\ Universitas Pendidikan Indonesia \\ Bandung, Indonesia \\ apriyandawijaya22@gmail.com
}

\author{
Rahmat Rahmat, Kokom Komalasari \\ Lecturers of Citizenship Education \\ Universitas Pendidikan Indonesia \\ Bandung, Indonesia \\ andeskarrahmat@gmail.com
}

\begin{abstract}
Learning is an interaction to gain knowledge, how to behave, and conduct useful behavior to increase capacity and someone's quality of life. learning citizenship education plays an important role for someone, especially students, to develop the potential to explore social experiences in order to become good citizens. For that reason, the students' interest in learning is increased, it needs a learning that is fun, well planned and wellconditioned. One way to make learning well-conditioned is by applying a learning model, for example role playing. This is what underlies the purpose of doing this research, namely to find out the reflective experience of students on the application of models role playing in learning civic education. The method used in this research is descriptive with a quantitative approach. The research subjects were students of class $X$ majoring in multimedia (MM-2) in Telkom Vocational School. The research data collection techniques used were observation, and questionnaires. Data analysis techniques using Microsoft Excel 2010. The results obtained from this study indicate that the reflective experience of students towards learning civic education that implements the integration of models role playing with multimedia is very good, because students explore their own learning experience, it is indicated by the activeness of students in completing given the project learning.
\end{abstract}

Keywords - learning experience; multimedia; role playing model

\section{INTRODUCTION}

Learning becomes a human process especially students to build meaning and knowledge on curiosity based on the development of the mind to later become part of an experience [1]. Learning is the core of the implementation of education programs in a country, because the implementation of learning goes hand in hand with the implementation of education. In Indonesia the National Education System is regulated in Law Number 20 of 2003 Concerning that education is a conscious and planned effort to create a learning atmosphere and learning process so that students actively develop their potential to have religious spiritual strength, self-control, personality, intelligence, noble character, and the skills needed in the community, nation and state. National education is education based on Pancasila and the 1945 Constitution of the Republic of Indonesia which is rooted in religious values, Indonesian national culture, and responsive to changing times. For this reason Citizenship Education plays an important role in the implementation of Education in Indonesia.

Citizenship education is a subject that is part of the National Curriculum, which is part of the government's efforts to instill ideology in its citizens. Citizenship Education is a subject that becomes the central goal of the education system with a critical, democratic thinking orientation, to prepare students to become good citizens [2], [3]. To realize students who are ready to become citizens of a democratic state, a learning model in the education unit is needed, especially in a class that is able to provide illustrations about the life of the community and state.

The role playing model is one of the models that is felt appropriate in illustrating the life of the community and the state. The model role playing is a role playing activity to explore feelings, teaches empathy, develops skills in students. This learning model will later create new experiences for students [4], [5]. The experience of these students is obtained through the play and evaluation conducted by each student with his group.

A good learning, besides paying attention to the application of the model also pay attention to the development of technology. Learning in the 21st Century is very concerned about the use of technology and information or multimedia. By using multimedia the learning will be more effective, the message of learning delivered and the values of life can be integrated optimally [6], [7], [8]

This article aims to explain how the reflective experience of students towards learning civic education that uses the integration of models role playing with multimedia. Ideally learning civic education that uses Integration of models role playing with multimedia can facilitate students to understand learning objectives, be able to understand the concept of the material, identify facts in the community, and be able to identify problems well. Thus the integration of the model role playing with multimedia in learning citizenship education has benefits that help implement an effective learning in helping the success of the program in the national education system. 


\section{THEORETICAL}

\section{A. Role Play Model}

In the process of learning the application of an appropriate model becomes important. One model that can be used to express enthusiasm and knowledge is the role playing model. Provides an understanding of the essence of role playing is the participation of researchers and students in actual problem situations to get the best solution. The process role playing serves to: explore students 'feelings, transfer and manifest views regarding students' behavior, values, and perceptions, develop problem solving skills and behavior, explore subject matter in different ways.

Provides an opinion about the purpose of role playing learning that is teaching about empathy to students [5]. Students are invited to experience activities that are seen based on other people's perspectives. Students are asked to imagine and feel what other people feel from what is being played, so that they also feel cared about what other people are feeling.

Based on some of these opinions it can be understood that the model of learning role playing is a learning model that involves the role of the teacher as director or controller and peseta students as a player as well as a researcher to foster a sense of empathy for the various roles played and displayed.

\section{B. Multimedia}

Multimedia is a change in how to communicate with each other. For example, in terms of sending and receiving information, it is now more effective and easier to understand. Heinich states that multimedia is a combination or integration of two or more media formats that combine, media such as text, graphics, animation, and video which then form the composition of information from a computer [6].

Munir stated that the use of multimedia in education has several features not shared by other media, namely: Multimedia in computer-based education, multimedia integrates various media (text, images, sound, video and animation) in one program digitally, Multimedia provides an interactive process and provides easy feedback, multimedia gives learners freedom in determining subject matter, and multimedia provides systematic control over learning [9].

Based on some of these opinions, researchers understand that multimedia learning is a modern learning in the current era is widely combined with existing technology, including the presence of multimedia today, such as displaying power points, images, animation, videos, songs, with this multimedia learning expected, learning material can be conveyed more fully, then students are better able to understand the material more easily, and also the atmosphere of learning is more fun.

\section{Integration of Role Playing Model with Multimedia}

Integration role playing model with multimedia is a learning model that combines learning models role playing or role playing with multimedia learning (power points, videos, pictures, songs) that are useful for developing students' skills in different learning ways to be more effective and easier to understand. The steps of implementing the model integration role playing with multimedia are as follows table I:
TABLE I. ThE STEPS OF IMPLEMENTING THE MOdEL INTEGRATION Role Playing With Multimedia

\begin{tabular}{|l|l|}
\hline Stage & \multicolumn{1}{|c|}{ Of the Learning Implementation Process } \\
\hline First & $\begin{array}{l}\text { Orientate about the model that will be applied by } \\
\text { displaying powerpoint learning material, video } \\
\text { learning related to learning material, and identify its } \\
\text { relation to learning material }\end{array}$ \\
\hline Second & $\begin{array}{l}\text { Determine groups for characterization such as } \\
\text { analyzing roles and selecting players who will } \\
\text { perform theRole }\end{array}$ \\
\hline Third & $\begin{array}{l}\text { Preparing researchers namely decide what to look } \\
\text { for and provide theobservation task }\end{array}$ \\
\hline Fourth & $\begin{array}{l}\text { Characterization is by starting role playing followed } \\
\text { by reinforcing role play and then completing role } \\
\text { playing. }\end{array}$ \\
\hline Fifth & $\begin{array}{l}\text { Discussing and evaluating through reviewing } \\
\text { characters (events, position and reality), discussing } \\
\text { the main focus and developing the next role }\end{array}$ \\
\hline Eighth & $\begin{array}{l}\text { Re-play is to play the changed role and provide } \\
\text { input or alternative behavior in the next step }\end{array}$ \\
\hline Seventh & $\begin{array}{l}\text { Share and generalize experience by connecting } \\
\text { situas i who have problems with life in the real } \\
\text { world and new problems emerge, explain general } \\
\text { principles in behavior } \\
\text { form of learning videos made by the group. }\end{array}$ \\
\hline Repeat the meaning of the group played into the \\
\hline form
\end{tabular}

\section{Methodology}

This study uses a quantitative approach with descriptive methods. In this study, there is one variable or independent variable, namely the integration of models role playing with multimedia in learning citizenship education. The sample in this study were students of class X Multimedia Department 2 (MM-2) totaling 36 students. Data collection tools use observation and questionnaire. Data analysis using Microsoft Excel 2010 application.

\section{DISCUSSION}

\section{A. Integration of Role Playing Models with Multimedia in Citizenship Education Learning}

Cogan which says that "Civic Education is the foundational course of work in school designed to prepare young citizens for an active role in their communities in adult there" [10]. For that learning civic education is required to be more realistic, through learning with role playing models in addition to adjusting the development of the times, namely by utilizing technology to be a source and media of learning or often referred to as multimedia learning. In this study, the researcher distributed questionnaire responses of students to the integration of models role playing with multimedia in learning civic education, then obtained a fairly good response of students to the application of this model integration. For more details in looking at the average value of students' responses to the implementation of the model role playing with multimedia in learning civic education can be seen in the tables of the calculation of Microsoft Excel 2010 below: 
TABLE II. Average VAlue (SCAle 1-5 ) THE RESUlts of Students RESPONSES TO THE APPLICATION OF THE INTEGRATION OF MODELS ROLE PLAYING WITH MULTIMEDIA IN LEARNING CITIZENSHIP EDUCATION

\begin{tabular}{|c|c|c|c|}
\hline No & Indicator & $\begin{array}{l}\text { Question } \\
\text { Number }\end{array}$ & $\begin{array}{l}\text { Average } \\
\text { Value }\end{array}$ \\
\hline 1 & $\begin{array}{l}\text { Orientation about the model to be } \\
\text { applied }\end{array}$ & $1-4$ & 4.2 \\
\hline 2 & $\begin{array}{lll}\begin{array}{l}\text { Determine } \\
\text { characterization }\end{array} & \text { groups } & \text { for } \\
\end{array}$ & $5-6$ & 4.1 \\
\hline 3 & Prepare researchers & $7-8$ & 4.21 \\
\hline 4 & Characteristics & $9-11$ & 4.26 \\
\hline 5 & Discuss and evaluate & $12-13$ & 4.06 \\
\hline 6 & Re-playing & $14-15$ & 4.22 \\
\hline 7 & $\begin{array}{lll}\begin{array}{l}\text { Sharing and } \\
\text { experiences }\end{array} & \text { generalizing } \\
\end{array}$ & $16-18$ & 4.1 \\
\hline 8 & $\begin{array}{l}\text { Re-pouring the meaning of the } \\
\text { group played }\end{array}$ & $19-20$ & 3.9 \\
\hline
\end{tabular}

Based on the calculation of Microsoft Excel 2010 in the table in above can be seen that the indicator "orienting about the model to be applied" produces an average value of 4.2 with the average value shows that by following the civic education learning that integrates the model role playing with multimedia students have been able to understand the power point of learning material displayed, learning videos related to learning material, and identify the relation with learning material.

Furthermore, on the indicator "determining groups for characterization" produces an average value of 4.1 with the average value shows that by following the civic education learning that integrates role playing model with multimedia students have been able to understand the stage of determining groups to characterization such as analyzing roles and selecting players who will play roles.

On the indicator "preparing the researcher" produces an average value of 4.21 with the average value shows that by following the civic education learning that integrates the role playing model with multimedia students have been able to well understand the stage of deciding what to look for and provide observation tasks.

In the "role" indicator produces an average value of 4.26 with the average value shows that by following the civic education learning that integrates models role playing with multimedia students have been able to understand and participate in the role play continued by confirming role playing then finishing role playing.

On the indicator "discuss and evaluate" produces an average value of 4.06 with the average value shows that by participating in civic education learning that integrates models role playing with multimedia students have been able to properly review characterization (events, positions, and reality), discuss the main focus-focus and develop the next role.

On the indicator "play back" produces an average value of 4.22 with the average value shows that by participating in learning civic education that integrates models role playing with multimedia students have been able to play a role that is changed and provide input or alternative behavior in the next step.
On the indicator "share and generalize experience" produces an average value of 4.1 with the average value shows that by following the civic education learning that integrates role playing model with multimedia students have been able to properly connect situations that have problems with life in the real world and new problems emerge, explain the general principles of behavior.

In the indicator "re-pouring meaning from the group played" produces an average value of 3.9 with the average value shows that by following the civic education learning that integrates role playing model with multimedia students have been able to properly re-mean the meaning from the group played into the form of learning videos made by groups.

\section{CONCLUSION}

Quality learning that the core of the successful implementation of education. For this reason educators must adjust the application of the learning model. One of the right learning models for learning citizenship education is the Integration of role playing model with Multimedia. This model is a learning model that combines role playing models with multimedia learning (power points, videos, images, songs) that are useful for developing skills, building meaning and knowledge from students 'curiosity which then becomes part of students' learning experience.

Based on the calculation of Microsoft Excel 2010 from the questionnaire data provided to students shows that the reflective practice of students, among others, is able to understand the learning material well through the application of the model integration role playing with multimedia as indicated by the average value of each indicator in the good category. This is certainly very helpful in the implementation of civic education learning. In addition to understanding learning materials, these students gain new experience in learning, by following learning that implements the integration of models role playing with multimedia students trained to think critically, democratically and indirectly as well prepare students to become good citizens.

\section{REFERENCES}

[1] Rusmana, Strategi Pembelajaran Dengan Problem Based Learning Untuk Meningkatkan Profesionalitas Guru, Jakarta: Ghalia Indonesia, 2012

[2] D. Budimansyah, "Revitalisasi Pembelajaran Pendidikan Kewarganegaraan Melalui Praktik Belajar Kewarganegaraan (Project Citizen)," Acta Civicus, vol. 1, No. 2, April 2008.

[3] N.M. Somantri, Menggagas Pembaharuan Pendidikan IPS, Bandung: PT. Remaja Rosdakarya, 2001

[4] A. Wicaksono, Teori Pembelajaran Bahasa: Suatu Catatan Singkat Edisi Revisi, Yogyakarta: Garudhawaca, 2016.

[5] A. Ismail, Ajarlah Mereka Melakukan: Kumpulan Karangan Seputar Pendidikan Agama Kristen, Jakarta: PT BPK Gunung Mulia, 1998.

[6] K. Komalasari, and S. Didin, "Nilai Berbasis Interaktif Pengembangan Multimedia melalui Praktek Terpadu untuk Pembentukan Karakter Siswa," The Turkish Online Journal of Educational Technology, vol. 16 , issue 4, Oktober 2017.

[7] S. S. Arief, Media Pendidikan, Jakarta: Raja Grafindo, 2007.

[8] Munadi, Yudhi, Media Pembelajaran, Jakarta: Gaung Persada, 2008. 
[9] Munir, Multimedia Konsep and Aplikasi dalam Pendidikan, Bandung: Alfabeta, 2012.
[10] J. J. Cogan, Developing the civic Society : The Role of Civic Education, Bandung : CICED, 1999. 